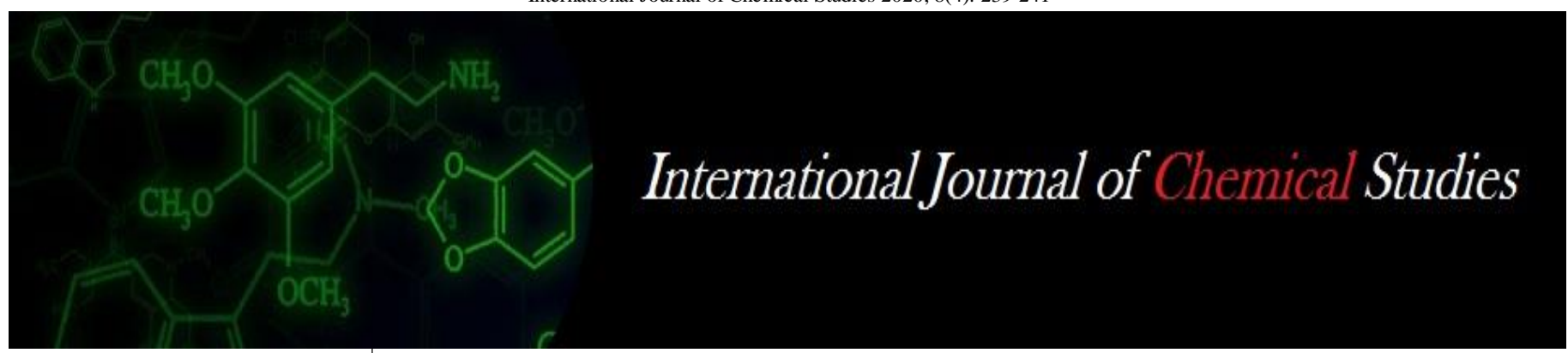

P-ISSN: 2349-8528

E-ISSN: 2321-4902

www.chemijournal.com

IJCS 2020; 8(4): 239-241

(C) 2020 IJCS

Received: 05-05-2020

Accepted: 08-06-2020

Animesh Chandravanshi

Ph.D Scholar, Department of

Farm Machinery and Power

Engineering, IGKV, Raipur,

Chhattisgarh, India

Dhananjay Roy

Assistant Professor, Sant Kabir

College of Agriculture and

Research Tation, Kawardha,

Chhattisgarh, India

\section{Ajay Verma}

Professor and Sr. Scientist,

Department of Farm Machinery and Power Engineering, IGKV,

Raipur, Chhattisgarh, India
Corresponding Author: Animesh Chandravanshi Ph.D Scholar, Department of Farm Machinery and Power Engineering, IGKV, Raipur, Chhattisgarh, India

\section{Investigation of physical properties of sugarcane stalk for the development of sugarcane detopper cum detrasher}

\author{
Animesh Chandravanshi, Dhananjay Roy and Ajay Verma
}

DOI: https://doi.org/10.22271/chemi.2020.v8.i4d.9697

\begin{abstract}
Sugarcane is mainly cultivated for sugar production in the world and is an important cash crop of India. It involves less risk and farmers are assured upto some extent about return in adverse condition. In Chhattisgarh sugarcane is cultivated in 0.30 lakh hectare and productivity is 41.6 ton/ha. The physical properties of the plant greatly influences the design of the major unit such as detopping, detrashing, conveyance and blower assembly of the sugarcane detopper cum detrasher. The various physical properties of 5 different varieties (Co-86032, Co-0265, Co-80036, and Co VSI-9805, and Co-085) of sugarcane are measured at farmer's field of Kabirdham district.
\end{abstract}

Keywords: Sugarcane, detopper, detrasher, detopping, blower

\section{Introduction}

Sugarcane cultivation in India is labor intensive process. Farmers mainly depend on human power throughout the season and now a day's scarcity of labor in agriculture sector is major problem. Hence mechanization is considered as an alternative to solve the problem of scarcity of labour. The major areas which require mechanization in sugar cultivation planting, harvesting and detrashing. The main aim of the project is to design a prototype of sugarcane detopper cum detrasher at low price so that it can be affordable to the farmers or group of farmers and that contributes mechanization of harvesting for ensuring cost effectiveness of sugarcane cultivation.

The physical properties of sugarcane play a significant role in designing the major components of sugarcane detopper cum detrasher. Physical properties such as length, diameter, node characteristics, leaf characteristics, amount of trash content of major varieties of sugarcane are measured. These properties are mainly depends on morphology of the sugarcane.

Moore and Nuss (1987) ${ }^{[5]}$ reported that the node consists of a growth ring or intercalary meristem, the root band (containing root primordial) and a bud above the leaf scar where the leaf sheath attaches, which delimits the node from the inter node. The transverse cross section through an inter node reveals vascular bundles surrounded by parenchyma cells with a thick outer epidermis covered in an external layer of wax.

Hunsigi (1993) ${ }^{[3]}$ reported that the optimum spacing for planting of sugarcane is 0.9 to $1.0 \mathrm{~m}$ between rows. In subtropical India, where growth of the plant is restricted due to climatic parameters, a row spacing of $0.75 \mathrm{~m}$ is adopted. Even though there are different planting systems for sugarcane, the ridges and furrows system of planting is very common in South India. The fields at different locations are studied for finding out the existing row spacing of the crop, to decide the optimum spacing of the crop divider and the effective width of the base cutter.

Bull A (2000) ${ }^{[2]}$ reported that inter node length can reach over $30 \mathrm{~cm}$, depending on growth conditions, and stems normally reach two to three metres in the normal growing season.

Miller and Gilbert A (2009) ${ }^{[4]}$ reported that the leaves are usually attached alternately to the nodes, thus forming two ranks on opposite sides. The mature sugarcane plant has an average total upper leaf surface of about 0.5 square metres and the number of green leaves per stalk is around ten, depending on variety and growing conditions. 
Bastian, and Shridar, (2014) ${ }^{[1]}$ studied the physical properties of sugarcane pertaining to de-topping, de-trashing and conveyance are studied for the designing of a whole stalk sugarcane harvester. The various physical parameters for the major varieties of sugarcane are measured in the farmers' field. The farmers' grow CO 86032 sugarcane at a row spacing of 75 to $100 \mathrm{~cm}$, and the spacing is increased to 150 and $200 \mathrm{~cm}$ wherever harvesting is done by self-propelled combine harvesters. The average number of cane per meter varied from 27 to 30 . The length of the millable cane varies between $1200 \mathrm{~mm}$ and $2700 \mathrm{~mm}$. The maximum and minimum diameters are 40 and $20 \mathrm{~mm}$ respectively. The trash content at the time of harvesting was 38.56 percent where the regular de-trashing processes were completely skipped by farmers.

\section{Materials and Methods}

Detrashing is the removal of leaves and tops from harvested cane stalk. The physical properties of the plant influence the detrashing operation, hence physiology of sugarcane plant is very important for the design of sugarcane detrasher. The various physical parameters such as length, diameter, weight, node characteristics, and amount of trash for the major varieties of sugarcane are measured in the farmer's field of Kabirdham district. Also the crop geometry measured in the same field.

\section{Physiology of Sugarcane Plant \\ Stalk}

Stalk is also known as "millable cane". It develops from the bud of seed-cane.

\section{Length of Cane}

Length of millable cane in the farmer's field is measured by $5 \mathrm{~m}$ measuring tape and recorded.

\section{Diameter of Cane}

Diameter of sugarcane varies from top to bottom and also depends on varieties. Diameter has an important role in designing detopping unit.

\section{Weight}

Weight of sugarcane stalk is one of the important parameter for selection of rollers and blades. The weight of single sugarcane stalk is recorded by digital load cell.

\section{Trash Content}

This is one the important parameter for design of sugarcane detopper cum detrasher. Trash content at the time of harvest depends on different varieties and agricultural practice adopted. The trash available at the time of harvest is removed mainly by two operation i.e. detopping and detrashing. The trash content removed by detopping and detrashing is recorded.

\section{Leaf and Node Characteristics}

The leaf of sugarcane plant grow alternately on opposite sides of the came stalk from the node the leaf of sugarcane plant is divided into two parts sheath and blade, separated by a blade joint. The sheath as its name implies, completely sheaths the stalk, extending over at least one complete internode.

Each joint is made up of a node and an internode. The node is where the leaf is attached to the stalk and where the buds and root primordial are found. A leaf scar can be found at the node when the leaf drops off the plant.

\section{Results and discussion}

Physical parameters of the sugarcane such as length, diameter and weight of millable cane and nodal characteristics are studied for the design and development of prototype of sugarcane detrasher.

\section{Length of matured cane}

Length of 5 different varieties of matured cane such as Co86032, Co-0265, Co-80036, CoVSI- 9805, and Co-085 are presented in Table 1. Among all the varieties Co-085 has highest average length i.e. $332.3 \mathrm{~cm}$.

\section{Diameter}

Diameter of the matured cane was measured in the same field. The diameter were measured at three different position viz. top, middle and bottom and presented in Table 2. The diameter of cane varied from top to bottom depends on varieties of the sugarcane.

\section{Weight}

Weight of sugarcane stalk varied from variety to variety and agricultural practices adopted by the farmers. The weight of single sugarcane stalk is measured by load cell. Among all the varieties Co 085 has highest $3.3 \mathrm{~kg}$ and 86032 has lowest i.e. $2.2 \mathrm{~kg}$.

\section{Node Distance}

Node distance of sugarcane stalk depends upon the variety of sugarcane. The node distance were measured at three different position viz. top, middle and bottom and presented in Table 4. were node distance at mid portion is highest as compared to top and bottom.

\section{Trash Content}

Trash content at the time of harvest depends upon the variety and agricultural practices adopted by the farmers and were regular detrashing skipped by the farmers of Kabirdham district. The trash content on cane basis were found highest in case of Co265 and lowest in case of Co80036 i.e. $31.1 \%$ and $25.5 \%$ respectively. Presented in Table 4

Table 1: Length of Different Varieties of Sugarcane

\begin{tabular}{|c|c|c|c|c|c|}
\hline Length (cm) & Co- 86032 & Co-80036 & Co-265 & Covsi-9805 & Co-085 \\
\hline Mean & 174.2 & 252.8 & 270 & 161.8 & 332.3 \\
\hline Maximum & 198 & 295 & 256 & 265 & 356 \\
\hline Minimum & 139 & 227 & 190 & 149 & 310 \\
\hline
\end{tabular}

Table 2: Diameter of Different varieties of Sugarcane

\begin{tabular}{|c|c|c|c|c|c|}
\hline Diameter (cm) & Co- 86032 & Co-80036 & Co-265 & Covsi-9805 & Co-085 \\
\hline Top & 2.67 & 2.63 & 2.71 & 2.76 & 2.6 \\
\hline Middle & 2.89 & 2.79 & 2.78 & 2.91 & 2.7 \\
\hline Bottom & 3.16 & 3.21 & 3.12 & 3.14 & 3.39 \\
\hline
\end{tabular}

Tab le 3: Weight of Single Stalk of Sugarcane

\begin{tabular}{|c|c|c|c|c|c|}
\hline Weight (kg) & Co- 86032 & Co-80036 & Co-265 & Covsi-9805 & Co-085 \\
\hline Mean & 2.2 & 2.6 & 3 & 2.8 & 3.3 \\
\hline Maximum & 2.5 & 3.1 & 3.5 & 3.3 & 3.8 \\
\hline Minimum & 1.8 & 2.1 & 2.9 & 2.3 & 2.6 \\
\hline
\end{tabular}

Table 4: Node distance of Different varieties of Sugarcane

\begin{tabular}{|c|c|c|c|c|c|}
\hline Diameter (cm) & Co- 86032 & Co-80036 & Co-265 & Covsi-9805 & Co-085 \\
\hline Top & 9.64 & 9.21 & 8.02 & 9.32 & 8.83 \\
\hline Middle & 12.03 & 11.05 & 11.48 & 11.41 & 12.08 \\
\hline Bottom & 7.08 & 6.14 & 7 & 6.71 & 6.9 \\
\hline
\end{tabular}


Table 5: Trash content

\begin{tabular}{|c|c|c|}
\hline S. No. & Variety of cane & Total trash on cane basis (\%) \\
\hline 1 & Co265 & 31.1 \\
\hline 2 & Co86032 & 27.7 \\
\hline 3 & Co80036 & 25.5 \\
\hline 4 & CoVSI9805 & 28.2 \\
\hline 5 & Co085 & 29.7 \\
\hline
\end{tabular}

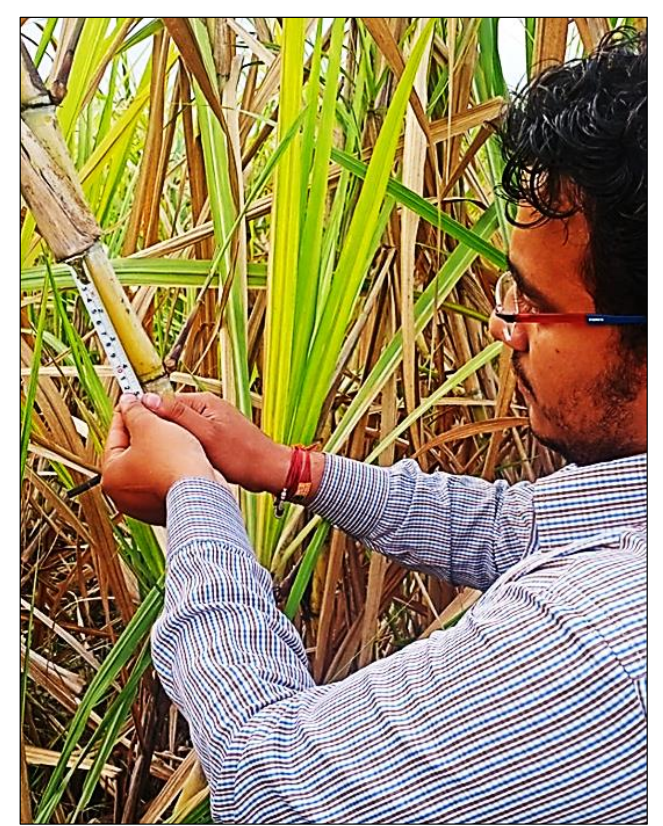

Fig 1: Measurement of physical properties of sugarcane

\section{Conclusion}

The study was undertaken to understand the requirement of sugarcane detrasher. The various physical parameters such as length, diameter and weight of millable cane, nodal characteristics and amount of trash content were studied at Kabirdham district. These properties play vital role in the development of sugarcane detopper cum detrasher. Among all the varieties Co-085 has highest average length i.e. $332.3 \mathrm{~cm}$. The diameter of cane varied from top to bottom depends on varieties of the sugarcane. The weight of single sugarcane stalk is measured by load cell. Among all the varieties Co 085 has highest $3.3 \mathrm{~kg}$ and 86032 has lowest i.e. $2.2 \mathrm{~kg}$. Node distance at mid portion is highest as compared to top and bottom. The trash content on cane basis were found highest in case of Co265 and lowest in case of Co80036 i.e. $31.1 \%$ and $25.5 \%$ respectively.

\section{Acknowledgement}

The first author is thankful to Swami Vivekanand College of Agricultural Engineering and Technology, IGKV Raipur (CG), for providing financial assistance and technical support to conduct the experiment.

\section{References}

1. Bastian J, Shridar B. Investigation on sugarcane detrashing mechanism. International journal of engineering and research. 2014; 3(7):453-457.

2. Bull T. The Sugarcane Plant. Chapter 4. In: M. Hogarth, P. Allsopp, eds. Manual of cane growing. Bureau of Sugar Experimental Stations, Indooroopilly, Australia, 2000, 71-83.

3. Hunsigi G. Prodution of sugarcane, Theory and Practice, Published online by Cambridge University, 1993, 157.
4. Miller JD, Gilbert RA. Sugarcane Botany- A Brief View. (SSAGR-234). Agronomy Department, Florida Cooperative Extension Service, Institute of Food and Agricultural Sciences, University of Florida, 2009.

5. Moore PH, Nuss KJ. Flowering and flower synchronization. Chapter 7. In: Eds: Heinz DJ. Sugarcane improvement through breeding. Elsevier, Amsterdam, 1987, 273-311.

6. Singh AK, Sharma MP. Development of an equipment to remove trash from harvested cane stalk for cleaning. In Souvenir of $43^{\text {rd }}$ Annual convention \& Symposium organized at Birsa Agricultural during Feb. 2009; 123: 15-17. 